\title{
Environmental Deterioration Factors in Metal Claddings and GFRC Panels Implemented on Facades: An Assessment through Two Cases in Istanbul
}

\author{
Sahar Manafvand Ardi ${ }^{1}$, Begum Diker ${ }^{2}$ and Payam Kanani Bahri ${ }^{3}$ \\ ${ }^{1}$ Faculty of Architecture, Istanbul Technical University, Taskisla Campus, 34437-Istanbul, Turkey, \\ saharmanafvand@gmail.com \\ ${ }^{2}$ Faculty of Art and Design, Dept. of Architecture, Dogus University, Acibadem Campus, 34722- \\ Istanbul, Turkey, bdiker@dogus.edu.tr \\ ${ }^{3}$ Faculty of Architecture, Istanbul Technical University, Taskisla Campus, 34437-Istanbul, Turkey, \\ payamkanani70@gmail.com
}

\begin{abstract}
Decrease in performance of building facades, components, and materials before their service life is an unexpected situation. Therefore, detecting the probable causes of these anomalies plays a crucial role in maintenance planning. This study aims to determine the environmental deterioration factors which affect the performance of buildings, especially building façades, through two case buildings situated in the same university campus in Istanbul. The methodological framework of the study is based on visual observations and literature review. Through observations on a different period of time, anomalies have been detected and photographed. In the first case, it has been focused on metal claddings on building façade. In the second case, it has been focused on GFRC panels which have the majority of the North façade. Within the help of literature and observations, two cases have been compared to each other in terms of their deterioration factors and interpreted through graphs. In the first case, occurred deteriorations have been detected such as uniform dirt, corrosion, joint degradation, mechanical impacts, and delamination. in the second case, deteriorations have been observed such as biological staining, uniform dirt, moisture rising, and design failures.
\end{abstract}

Keywords: Environmental Deterioration Factors, Building Façade Failures, Metal Claddings, Glass Fibre Reinforced Concrete Façade.

\section{Introduction}

Performance of a building deteriorates in time depending on environmental effects, usage, maintenance, detail design and type of materials which are used in building envelope. Therefore, defining the probable causes of deteriorations has high importance to propose appropriate solutions.

Environmental agents are divided into natural (wind, rain, freeze and throw, and solar radiation), and chemical and biological problems, issued by air pollution (Norvaišienè et al., 2003). The data reported in this paper investigates environmental agents which can affect performance of façade.

A research called "Climatic and Air Pollution Effects on Building Facades" has a deep literature review on degradation mechanisms that affect the durability of building materials (Norvaišienè et al., 2003). A study called "Evaluation of Damage of Building Facades in Brasilia" aims to evaluate age and climatic agents through quantitative research. Visual inspections and facade mapping were used as a method and some degradation agents such as grout and sealing failures and efflorescence are examined over the exposure to solar radiation 
(Bauer et al., 2014). By now, many kinds of research have been done on deterioration factors and durability of materials. Defining these factors/mechanisms correctly is essential in order to propose appropriate solutions in design, construction, and maintenance process.

\section{Environmental Factors}

Mechanisms are generally examined in three categories: physical, chemical, and biological (Dickinson et al., 1999). Physical mechanisms are related to the presence of water. Freezing and thawing processes with the temperature and moisture differences may cause stress and crack on the material (Norvaisiene et al., 2003). Chemical mechanisms involve some chemical compounds that can react with the building surface. Particulate matters in the air generally comprise dust, smoke and suspended particles. Dust particles being large and heavy, settle quickly and will not affect large areas. Smoke and suspended particles being smaller and lighter remain in the atmosphere for a longer time and affect larger areas (Chew et al., 2003). Sulfur and nitrate have acidic concentrations, and they cause acid rain, which is a threat to human health and also building envelope (Norvaisiene et al., 2003). Besides, corrosion of materials can occur due to chemical interaction with the environment. If corrosion of materials does not prevent in time, it may cause even structural deteriorations.

In biological mechanisms, wind changing the direction of rain drops to façade and this is "one of the most important moisture sources" that effects durability of façade material. These destructive effects can be "frost damage, discoloring, biological and chemical degradations"

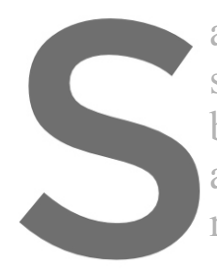
and also structural cracking (Blocken ef al.,
stains on façade. It can wash the dirt through th
biological grow on it. "Sunlight plays an impo
a facade. The intensity and duration of sunli
runoff flow, the type of biological stains and th
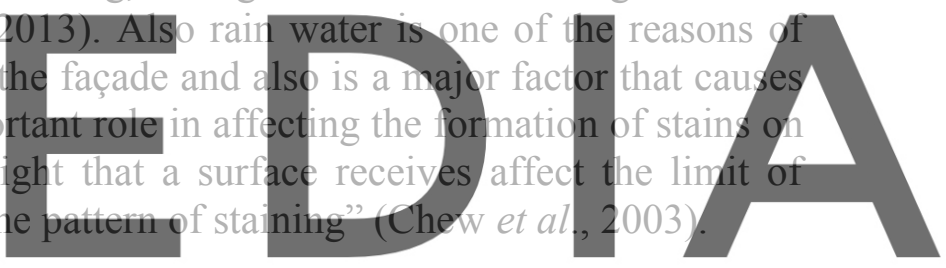

\section{Case Studies}

Register for free at https//www.scipedia.com to download the version without the watermark In this part, two case buildings where are located in Istanbul are selected in order to understand environmental deterioration factors. In this context, there is an approach from macro to micro scale, which begins with defining the surrounding of the buildings and continues with the building facade components.

\subsection{Local Environment}

Both of the case buildings are located in Maslak, where is one of the main business districts of İstanbul. The altitude is 120 meters, and distance from the sea is approximately $3 \mathrm{~km}$. In the first case, the northern facade of the building is facing Buyukdere Street, which usually has heavy traffic flow. Also, there is viaduct which is passing near the case building and facing the northern facade of the first case building again. The other side of Buyukdere is a highdensity urbanized area which has many commercial and residential complexes.

In the second case building, traffic direction is in North and East face. There is also a parking lot in the West side. The site plans of the case buildings are given in Figure 1: 

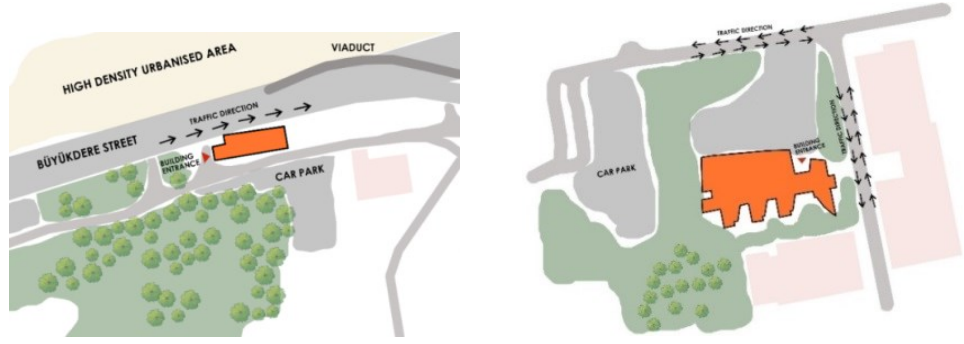

Figure 1. Site plans of the first and second case buildings.

\subsection{Micro Environment}

Istanbul where the case buildings are located has mild-humid climatic characteristics. According to the official statistics, the highest temperature is in July $\left(41.5^{\circ} \mathrm{C}\right)$, and the lowest average temperature is in February $\left(-16.1^{\circ} \mathrm{C}\right)$. The average number of rainy days is highest in January (17.3) and the lowest in July (4.3). Maximum daily precipitation is $128.9 \mathrm{~mm}$ (Turkish State Meteorological Service Official Web Sites, n.d.).

The dominant wind direction in the district is North - North East. Accordingly, it is assumed that the northern façade of the building is exposed to more wind and rain. Figure 2 shows the location of the case buildings in macro scale. Distance from the sea is approximately $3 \mathrm{~km}$ that can be an adequate distance to happen convection of salt.
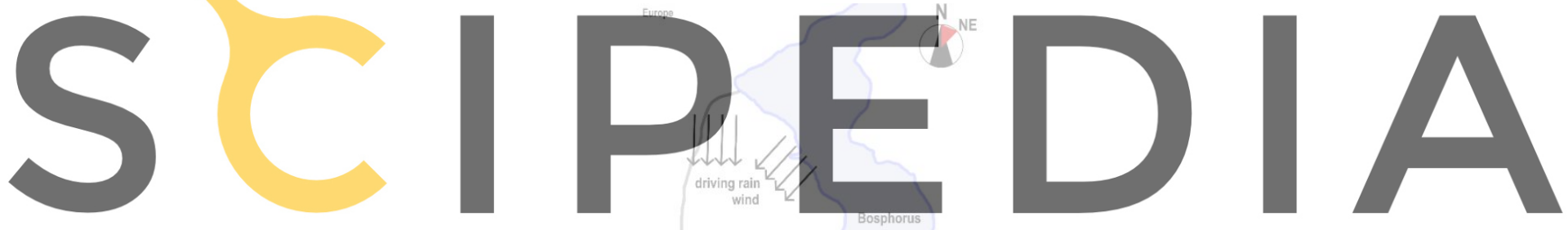

Register for free at https//www.scipedilat,com to download the version without the watermark

Figure 2. Location of the case buildings.

The recent measurements performed by Ministry of Environment and Urbanization show that PM10 and $\mathrm{NO}_{2}$ values are comparatively increasing in the rush hours as a probable consequence of Buyukdere Street (SIMM Project n.d.). Also, a report which has been prepared in 2018 by the Netherlands Enterprise Agency shows the existing situation within the context of air pollution in İstanbul. According to the European Directive, the number of permitted exceedances per year is 18 . Figure 3 shows that $\mathrm{NO}_{2}$ limit is exceeded more than 18 times in 6 stations in 2017 and Maslak district has the third highest exceedance level (Standards-Air Quality-Environment-European Commission, n.d.). As understood, the selected buildings are located in a highly urbanized area and air pollution in the district is quite a lot. Therefore, the selection of appropriate material for the building envelope is a critical issue. 


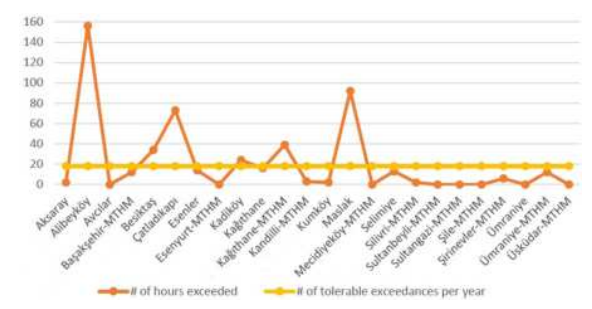

Figure 3. Frequency of hours the $\mathrm{NO}_{2}$ limit was exceeded in 2017.

\subsection{Facade Components}

The first case building facade mainly has $4 \mathrm{~mm}$ thickness white colored aluminum composite panel (1), siliconized glass system with an aluminum frame (2), structural steel columns (3), natural stone cladding (4), silver-gray colored aluminum mesh cladding (5) and white colored aluminum dynamic vertical and fixed horizontal shading elements (6) (Figure 4).

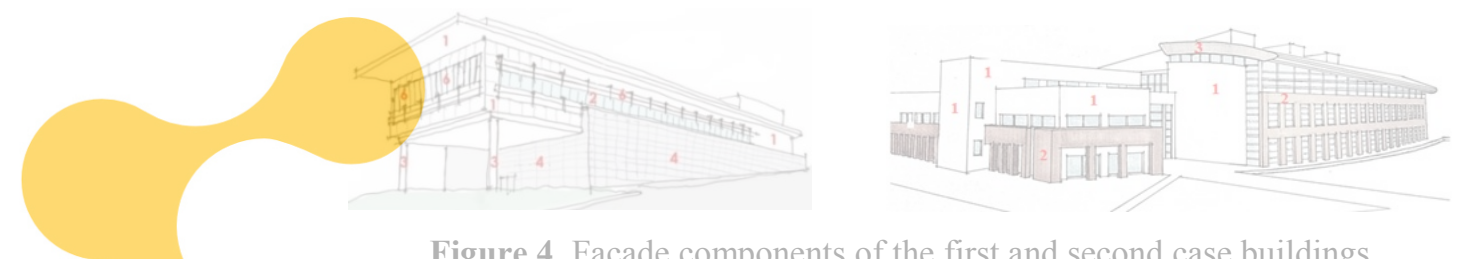

Figure 4. Façade components of the first and second case buildings.

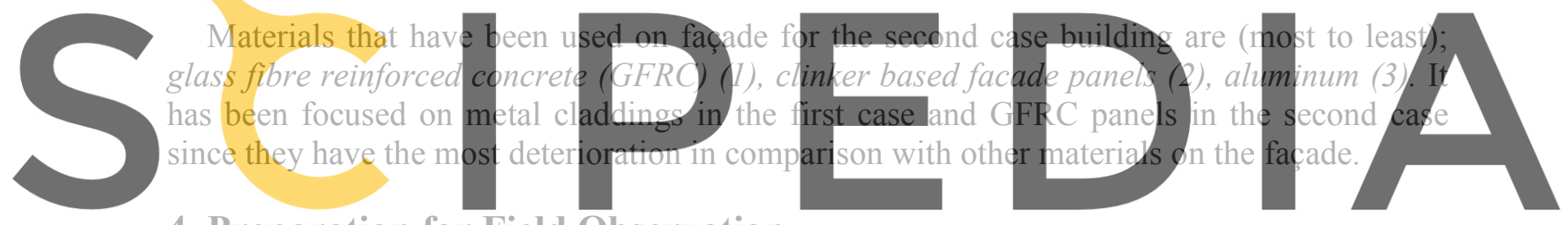

4 Preparation for Field Observation

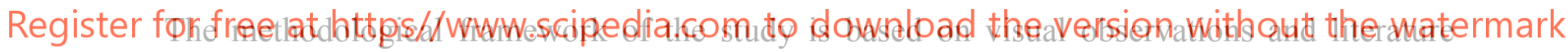
review. Firstly, façade deterioration factors have been defined in detail through literature. For the field observation, two datasheets have been prepared. The first datasheet contains the general information such as primary use of the building and construction process. The second one involves atmospheric exposures such as wind, rain, sun that affects the building façades, climate in the observation days and deterioration types. After collecting data, anomalies on building façade have been detected and shown in façade mapping (Figure 5).

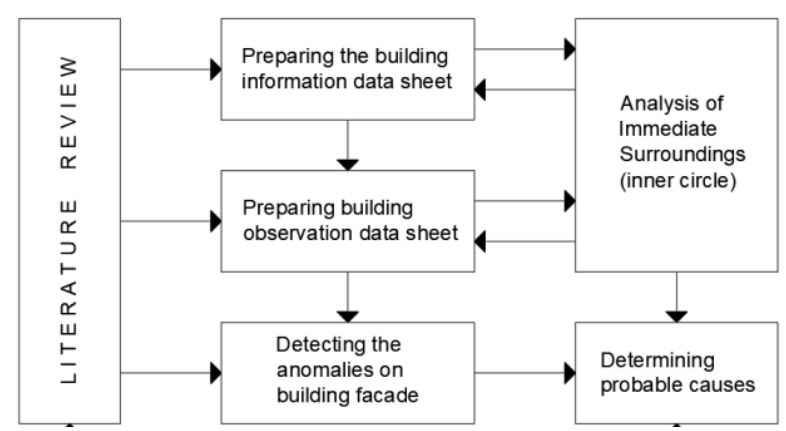

Figure 5. The methodology of the study. 


\section{Analysis and Discussions}

For the first case building, four observations were made. The first one was made on $27^{\text {th }}$ April 2015 , in a cloudy day, $18^{\circ} \mathrm{C}$ at 09:30 am. The second one was on $25^{\text {th }}$ September 2018 , rainy day, $19^{\circ} \mathrm{C}$. The third one was $9^{\text {th }}$ October 2018 , cloudy day, $16^{\circ} \mathrm{C}$ at $12: 00$ am and the fourth observation was on $4^{\text {th }}$ December 2018 , after rain, $10^{\circ} \mathrm{C}$ at $05: 30 \mathrm{pm}$.

For the second case, the first observation was in $22^{\text {th }}$ October $2018,15: 35$ in partly cloudy weather. The second one was in $10^{\text {th }}$ November 2018, 17:09 in a completely sunny weather. The last observation was made after two heavy rainy days in $19^{\text {th }}$ November 2018, 14:22.

\subsection{Case Study 1}

According to the observations, anomalies detected on the selected building facades are examined. Deteriorations are classified into five categories. These are; uniform dirt (A), corrosion (B), joints degradation (C), mechanical impact (D), and delamination (E). The deteriorations which have been detected are shown in façade mapping (Figure 6).

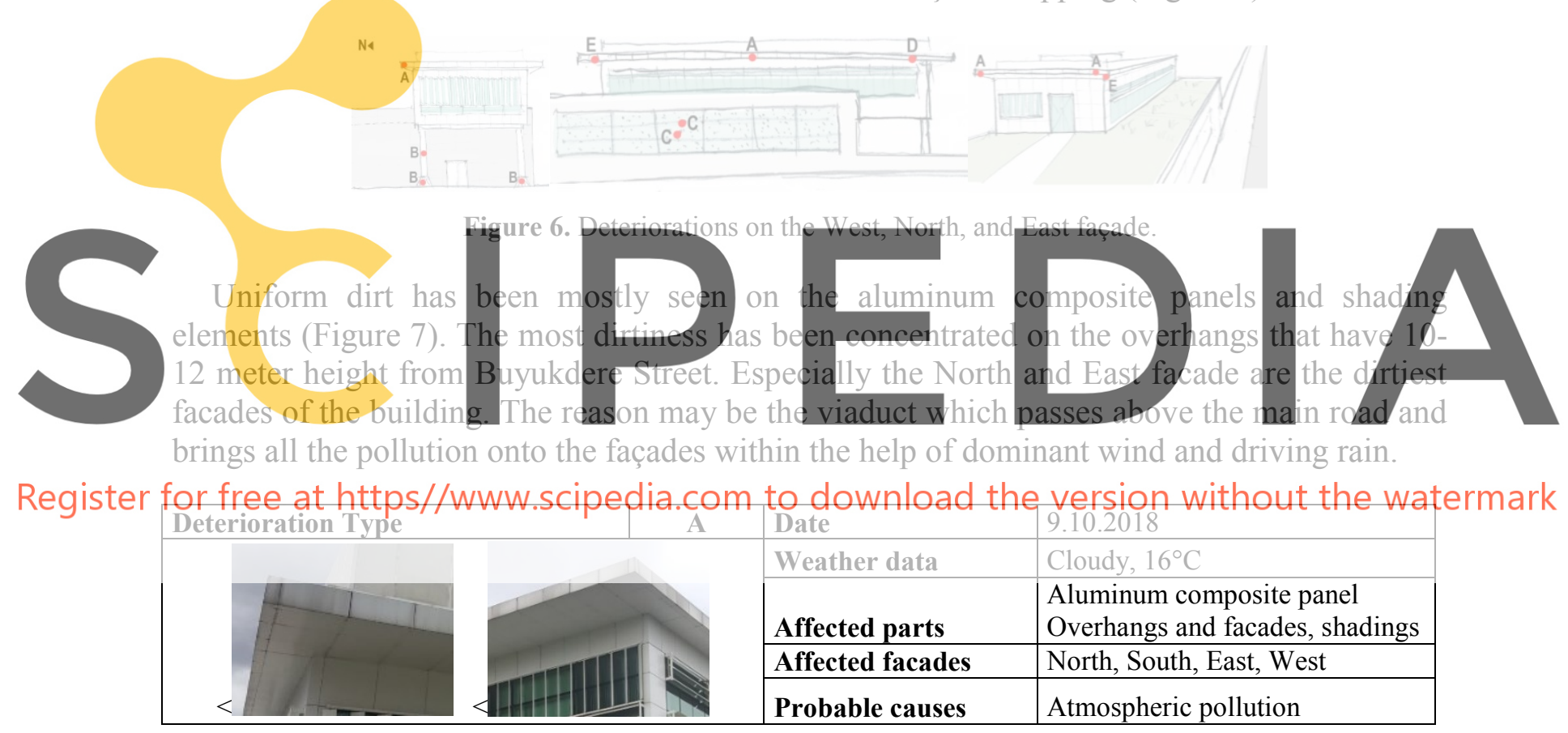

Figure 7. Deterioration type A, 'uniform dirt'.

The observations which have been made in $25^{\text {th }}$ September and $4^{\text {th }}$ December 2018 show that two structural columns on the West façade of the building have been deteriorated by corrosion effect (Figure 8). The waterhole has been observed below the feet of the column after the rain. Accordingly, degradation on the feet is thought to be due to the wrong slope angle. Deterioration on the column head may be related with the storm water runoff. 


\begin{tabular}{|l|l|l|l|}
\hline Deterioration Type & B & Date & $25.09 .2018,04.12 .2018$ \\
\hline \multirow{5}{*}{} & Weather data & Rainy, $19^{\circ} \mathrm{C}$, after rain $10^{\circ} \mathrm{C}$ \\
\cline { 3 - 4 } & \multirow{3}{*}{$\begin{array}{l}\text { Affected parts } \\
\text { Affected facades }\end{array}$} & $\begin{array}{l}\text { Structural steel column } \\
\text { column head, body, and feet }\end{array}$ \\
\cline { 3 - 4 } & & $\begin{array}{l}\text { West } \\
\text { atmospheric pollution } \\
\text { srong slope (ground level) } \\
\text { stormwater runoff }\end{array}$ \\
\hline
\end{tabular}

Figure 8. Deterioration type B, 'corrosion'.

According to the observation on 9th October 2018, joints degradations have been detected on the North façade, which has covered with aluminum mesh cladding (Figure 9). This deterioration may be the consequence of stiff breeze coming from the North and North-East direction. Also, wrong detail design may cause to happen in this situation.

\begin{tabular}{|c|c|c|c|}
\hline Deterioration Type & $\mathrm{C}$ & Date & 9.10 .2018 \\
\hline & & Weather data & Cloudy, $16^{\circ} \mathrm{C}$ \\
\hline & & Affected parts & Aluminum mesh cladding \\
\hline & & Affected facades & North \\
\hline - & & Probable causes & $\begin{array}{l}\text { Atmospheric effects (wind, rain) } \\
\text { wrong detail design (WDD) }\end{array}$ \\
\hline
\end{tabular}

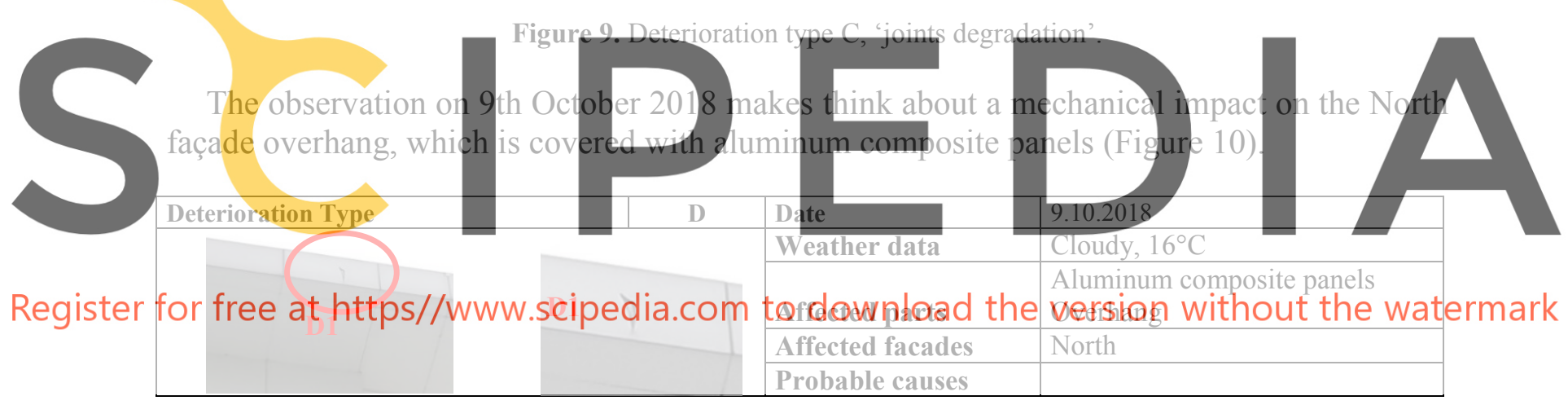

Figure 10. Deterioration type D, 'mechanical impact'.

According to the observation on 4th December 2018, delamination is seen on the North and East overhangs (Figure 11). Probable cause is thought to be the storm water runoff with the wind which is coming from the dominant direction. It may have penetrated from the joints and caused the delamination of layers on the composite panels.

\begin{tabular}{|l|l|l|l|}
\hline Deterioration Type & E & Date & 4.12 .2018 \\
\hline \multirow{4}{*}{ E1 } & Weather data & After the rain, $10^{\circ} \mathrm{C}$ \\
\cline { 3 - 4 } & & $\begin{array}{l}\text { Aluminum composite panels } \\
\text { Overhang }\end{array}$ \\
\hline & & Affected parts & North, East \\
\cline { 3 - 4 } & Affected facades & Stormwater runoff \\
& Probable causes & \\
\hline
\end{tabular}

Figure 11. Deterioration type E, 'delamination' 


\subsection{Case Study 2}

According to the observations, anomalies detected on the selected building facades are examined. Deteriorations are classified into three categories. These are; biological staining (A), moisture rising (B), and joints degradation (C). The deteriorations which have been detected are shown in façade mapping (Figure 12).

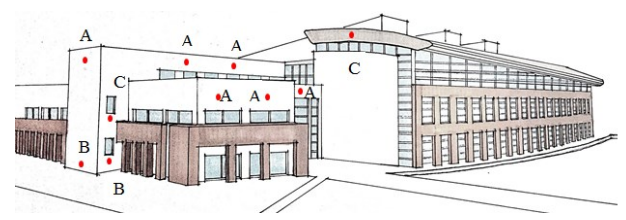

Figure 12. Façade mapping of the second case building.

According to observations, the building is exposures to the prevailing wind, which changes the direction of raindrops. As the most deteriorated part of the façade is the N/E (Figure 13), lack of sunlight slowdowns the procedure of drying after it had been wetted, and results as biological staining (due to algae, bacteria, and fungi).

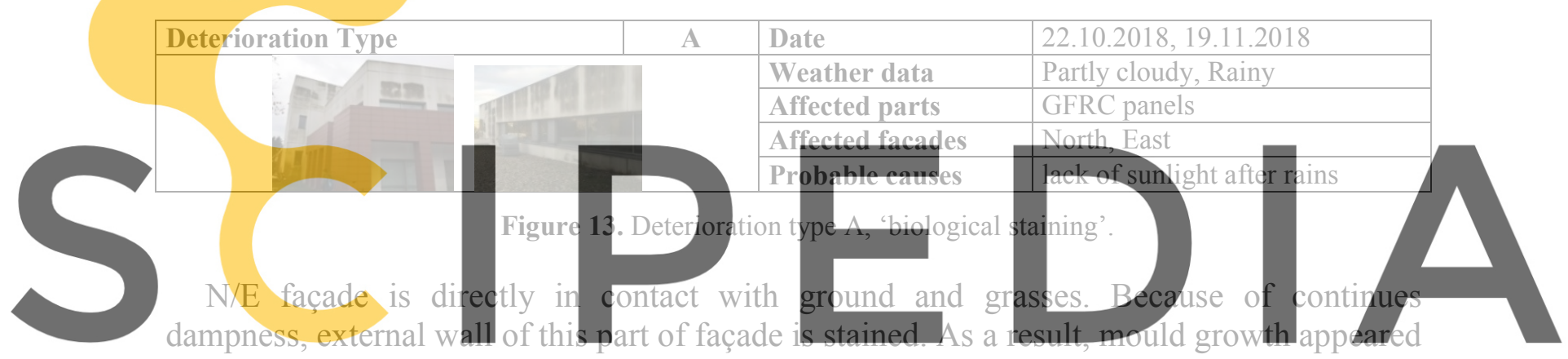
and there was discoloration to the wall (Figure 14).

Register for free at https//www.scipedia.com to download the version without the watermark Deterioration Type

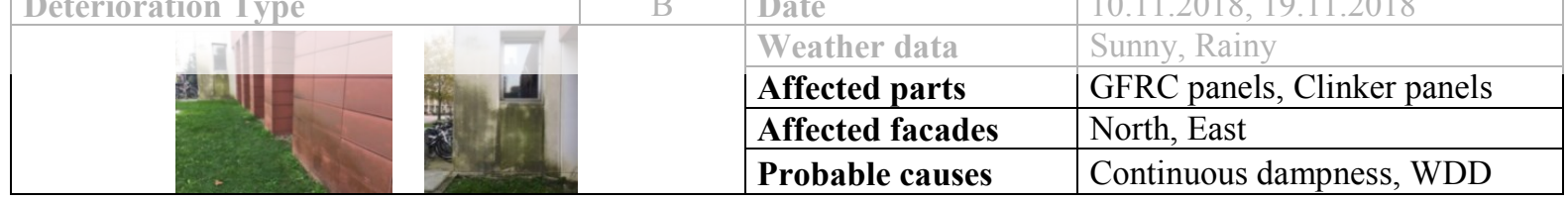

Figure 14. Deterioration type B, 'moisture rising'.

Panel joints and sealants on a façade provide for drainage of run-off on the facade. Joints affect runoff can locally rinse away deposited dirt stains at areas where a file of vertical joints is broken and where joints are slanted (Figure 15).

\begin{tabular}{|l|l|l|l|}
\hline Deterioration Type & C & Date & $10.11 .2018,19.11 .2018$ \\
\hline \multirow{3}{*}{} & & Weather data & Sunny, Rainy \\
\cline { 3 - 4 } & Affected parts & GFRC panels, Aluminum \\
\cline { 3 - 4 } & Affected facades & North, East \\
\cline { 3 - 4 } & & $\begin{array}{l}\text { Atmospheric effects (wind, rain) } \\
\text { wrong detail design }\end{array}$ \\
\hline
\end{tabular}

Figure 15. Deterioration type C, 'Joints degradation'. 


\section{Conclusion}

In this study, field observation has been done for two case buildings, and probable causes on façade deteriorations have been examined with the help of literature.

The district of both cases has air pollution due to high urbanization and heavy traffic intensity. Especially in the first case, some deteriorations have been observed after only three years of usage on the North, East, and West façades which are close to the main road and the viaduct. According to the literature, aluminum composite panels should be cleaned at least once in a year. Besides, stormwater runoff should be controlled to prevent the corrosion of steel materials. To delay or prevent necessary significant renovations for the future, maintenance planning should be done and implemented periodically.

This paper helps to understand the expected behavior of GFRC panels and metal claddings for Istanbul province and similar climatic conditions. More data and laboratory analysis is required for this method to produce more reliable façade degradation mapping.

\section{ORCIID}

Sahar Ardi Manafand: https://orcid.org/0000-0002-0326-017X

Begum Diker: http://orcid.org/0000-0001-9149-3880

Payam Kanani Bahri: https://orcid.org/0000-0003-1951-9534

\section{References}

Bauer, E., Kraus, E., Silva, M. N. and Zanoni, V. A. (2014). Evaluation of Damage of Building Facades in Brasilia. XIII Internation 542). Sao Paulo: RILEM P

Blocken, B., Derome, D. and Environment, Elsevier Ltd. Chew, M. and Tan, P. Materials, 17(3), 181-187. https:
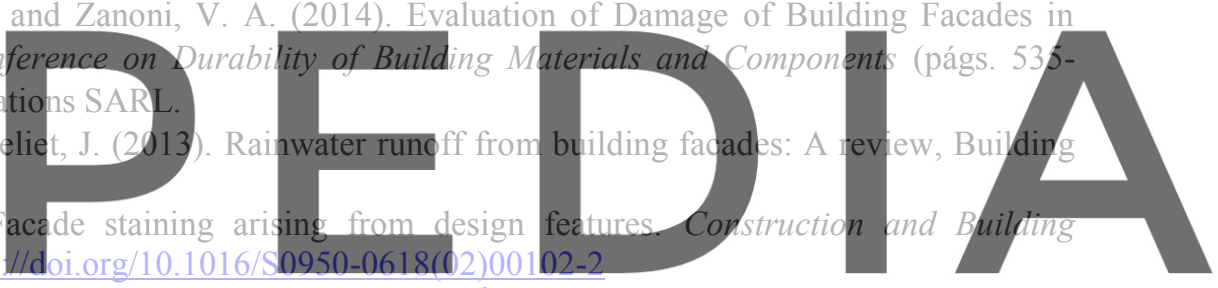

Dickinson, H. S. and C, J. J. (1999). Effects of Air Pollution on Historic Buildings and Monuments and the

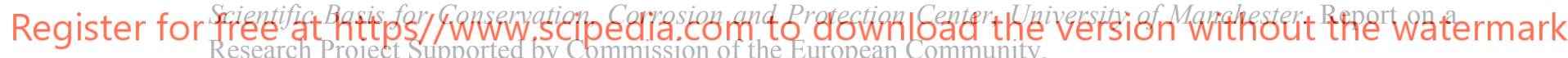

Flores-Colen, I. and Brito, J. d. (2010). A Systematic Approach for Maintenance Budgeting of Buildings Facades Based on Predictive and Preventive Strategies. Construction and Building Materials(24), 1718-1729.

Galbusera, G., Brito, J. d. and Silva, A. (2014). The importance of the quality of sampling in service life prediction. Construction and Building Materials(66), 19-29.

Madureira, S., Flores-Colen, I., Brito, J. d. and Pereira, C. (2017). Maintenance Planning of Facades in Current Buildings. Construction and Building Materials(147), 790-802.

Mohaney, P. and Soni, E. G. (January 2018). Aluminium Composite Panel as a Facade Material. International Journal of Engineering Trends and Technology (IJETT), 75-80.

Norvaisiene, R., Miniotaite, R. and Stankevicius, V. (2003). Climatic and Air Pollution Effects on Building Facades. Materials Science (Medziagotyra), 9(1), 102-105.

SIM Project. (n.d.). Retrieved September 29, 2019, from https://sim.csb.gov.tr/Services/Details?id=6b7a98401e13-4045-a79d-0f881c4852ad

Standards-Air Quality_Environment_European Commission. (n.d.). Retrieved September 29, 2019, from https://ec.europa.eu/environment/air/quality/standards.htm

Turkish State Meteorological Service Official Web Sites. (n.d.). Retrieved September 29, 2019, from https://mgm.gov.tr/eng/forecast-cities.aspx 